\author{
MARTA OBARA-MICHLEWSKA \\ Zakład Neurotoksykologii \\ Instytut Medycyny Doświadczalnej i Klinicznej im. M. Mossakowskiego PAN \\ Pawińskiego 5, 02-106 Warszawa \\ E-mail: mobara@imdik.pan.pl
}

\title{
WPEYW SNU NA FUNKCJONOWANIE UKŁADU GLIMFATYCZNEGO
}

\section{WSTEP}

W mózgu, w przeciwieństwie do pozostałych narządow i tkanek organizmu, nie występuja naczynia limfatyczne. W jaki więc sposób, skoro nie dzięki przepływowi limfy, utrzymywana jest w mózgu prawidłowa objętość płynów oraz, jak następuje odprowadzanie gromadzących się zbędnych produktów przemiany materii, uszkodzonych komórek i innych niepożądanych, potencjalnie szkodliwych, substancji? Pytanie to postawiła prof. Maiken Nedergaard (Uniwersytet w Rochester, USA), kwestionujac w znacznej mierze ówczesny stan wiedzy, według którego za powyższe procesy fizjologiczne odpowiadać miałby bierny przepływ płynu mózgowo-rdzeniowego. Badania prof. Nedergaard doprowadziły ja do uzupełnienia dotychczasowego niesatysfakcjonujacego modelu i zaproponowania koncepcji „układu glimfatycznego", będaccego funkcjonalnym odpowiednikiem układu limfatycznego w mózgu (ILIFF i współaut. 2012).

Celem ułatwienia zrozumienia zjawisk związanych $z$ aktywnością układu glimfatycznego, na wstępie omówione zostana podstawy dotyczace powstawania i przepływu płynu mózgowo-rdzeniowego oraz budowa opon mózgowych.

Płyn mózgowo-rdzeniowy powstaje, jako przesacz osocza krwi, głównie w splotach naczyniówkowych, strukturach znajdujacych się w komorach mózgu. W porównaniu do osocza, płyn mózgowo-rdzeniowy ma niższe stężenie jonów potasu, wapnia i magnezu, a wyższe jonów chloru, oraz jest niemal całkowicie pozbawiony białek. Płyn mózgowo- -rdzeniowy wypełnia układ komorowy i kanał rdzenia kręowego oraz przestrzeń podpajęczynówkowa, tj. przestrzeń pomiędzy opona mózgowo-rdzeniowa pajęczą a opona miękką. U człowieka powstaje dziennie nawet do $500 \mathrm{ml}$ płynu mózgowo-rdzeniowego, ponieważ jednak jest on jednocześnie wchłaniany, w danym momencie w mózgu znajduje się go ok. $160 \mathrm{ml}$. Objętość ta stanowi zaledwie 10\% całkowitej objętości wody, stanowiącej aż 85\% masy mózgu. Większość (60-68\%) to woda obecna wewnattrz komórek, kolejne $10 \%$ to woda będaca składowa krwi, a pozostałe $12-20 \%$ to woda wypełniająca przestrzenie między komórkami (płyn międzykomórkowy). Płyn międzykomórkowy, w odróżnieniu od płynu mózgowo-rdzeniowego, zawiera oprócz jonów także uwalniane przez komórki enzymy, neurotransmitery, pęcherzyki wydzielnicze, cytokiny itd. Wraz $z$ płynem międzykomórkowym w przestrzeni międzykomórkowej znajduje się także macierz zewnatrzkomórkowa, platforma interakcji molekularnych niezwykle złożona pod względem strukturalnym i funkcjonalnym (KHASAWNEH i współaut. 2018, SHETTY i ZANIRATI 2020).

Opony mózgowo-rdzeniowe to trzy łacznotkankowe błony otaczajace mózg i rdzeń kregowy: opona twarda (zewnętrzna), pajęcza (środkowa) i opona miękka, bezpośrednio przylegająca do powierzchni mózgu i rdzenia. Pajęczynówka łączy się $z$ opona miękka pasmami i beleczkami łacznotkankowymi, a powstajaca $w$ ten sposób przestrzeń (przestrzeń podpajęczynówkowa) wypełnia płyn mózgowo-rdzeniowy. Pajęczynówka formuje uwypuklenia, tzw. ziarnistości, które wnikaja 


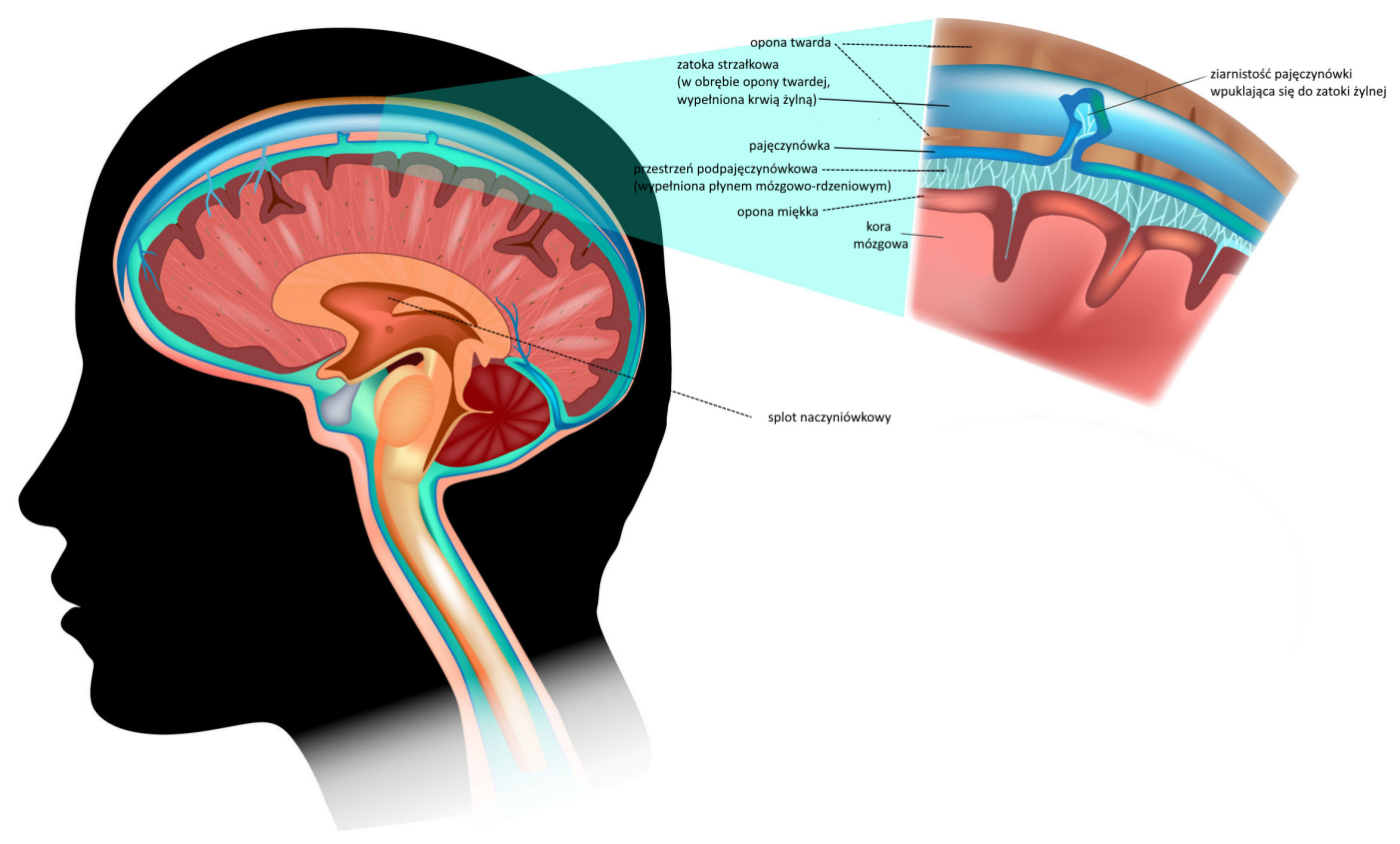

Ryc. 1. Schemat obrazujacy opony mózgowo-rdzeniowe wraz z ziarnistościami pajęczynówki oraz przestrzeń podpajęczynówkowa wypełnioną płynem mózgowo-rdzeniowym, powstającym w splocie naczyniówkowym.

do zatok żylnych znajdujących się w obrębie opony twardej (Ryc. 1). Największe, ale nie jedyne, ziarnistości leżą wzdłuż zatoki strzałkowej górnej. Przepływ płynu mózgowo-rdzeniowego przez ziarnistości jest, dzięki gradientowi ciśnienia, jednokierunkowy: ciśnienie płynu mózgowo-rdzeniowego jest większe niż ciśnienie krwi. Nawet w przypadku patologicznego odwrócenia się gradientu ciśnień, płyn nie zmienia kierunku przepływu, jednak mechanizm tego zjawiska nie jest poznany. W większym stopniu niż przez ziarnistości pajęczynówki, płyn mózgowo-rdzeniowy opuszcza mózg i czaszkę wzdłuż nerwów czaszkowych, głównie czaszkowego I (węchowego), przez blaszkę sitowa i trafia do szyjnych naczyń limfatycznych. Wraz z przełomowym odkryciem w 2015 r. naczyń limfatycznych leżacych w obrębie opony twardej (ASPELUND i współaut. 2015, LOUVEAU i współaut. 2015, ABSINTA i współaut. 2017), ujawniła się trzecia możliwa droga odprowadzania płynu mózgowo-rdzeniowego, tj. poprzez ziarnistości pajęczynówki do oponowych naczyń limfatycznych.

\section{MECHANIZM DZIAEANIA UKŁADU GLIMFATYCZNEGO ORAZ TECHNIKI BADANIA JEGO AKTYWNOŚCI}

Funkcjonowanie układu glimfatycznego polega na zastapieniu „zanieczyszczonego" płynu międzykomórkowego wraz z rozpuszczonymi w nim zbędnymi substancjami (produktami komórkowej przemiany materii - jonami, białkami, tłuszczami etc.), nowopowstałym płynem mózgowo-rdzeniowym, i przywróceniu $w$ ten sposób środowiska prawidłowego dla funkcjonowania komórek nerwowych (JESSEN i współaut. 2015). Płyn mózgowo-rdzeniowy $z$ komór mózgu przepływa do przestrzeni podpajęczynówkowej, a następnie wnika w głąb tkanki mózgu wzdłuż naczyń tętniczych, tzw. przestrzeniami okołonaczyniowymi (przestrzeniami Virchowa-Robina). Przepływ płynu mózgowo-rdzeniowego wzdłuż tętnic jest zgodny $z$ kierunkiem przepływu krwi i wspomagany przez pulsację ścian tętnic, wywołana praca serca (ILIFF i współaut. 2013). Wraz ze zwężaniem się średnicy naczyń krwionośnych zmniejsza się i zanika przestrzeń okołonaczyniowa - powierzchnia kapilar jest niemal całkowicie pokryta przez wypustki komórek glejowych, astrocytów, współtworzacych w ten sposób barierę krew-mózg (VERKHRATSKY i współaut. 2019). Płyn mózgowo-rdzeniowy $z$ przestrzeni okołonaczyniowej przechodzi więc do przestrzeni międzykomórkowej, a astrocyty aktywnie $\mathrm{w}$ tym uczestnicza, regulujac transport wody, jonów i substancji rozpuszczonych. Wyjątkowość odkrycia prof. Nedergaard polegała w dużej mierze na wykazaniu, że kluczowa dla funkcji układu glimfatycznego jest obecność akwaporyny 4 (Aqp4), białka zlokalizowanego w błonach komórkowych astrocytów (ILIFF i współaut. 2012, MESTRE i współaut. 2018, ZHANG i 
współaut. 2020). Aqp4 to kanał wodny, umożliwiajacy selektywny i szybki transport cząsteczek wody. U myszy, u których dokonano modyfikacji genetycznej polegajacej na usunięciu (knock-out, KO) Aqp4 z astrocytów, układ glimfatyczny był znacznie mniej wydajny. Płyn mózgowo-rdzeniowy, stopniowo mieszajacy się $z$ płynem międzykomórkowym i niejako zastepujacy go, jest kierowany do przestrzeni okołonaczyniowych, ale teraz wzdłuż naczyń żylnych. Dalej, zgodnie $z$ kierunkiem przepływu krwi, wraz ze zbędnymi substancjami, płyn kierowany jest $z$ powrotem do przestrzeni podpajeczynówkowej, skąd, dzięki jednokierunkowemu przepływowi, odprowadzany jest do zatok żylnych, aby następnie opuścić mózg przez naczynia krwionośne i/lub limfatyczne, położone w obrębie opony twardej. Jak wspomniano wyżej, płyn mózgowo-rdzeniowy, po przejściu przez przestrzenie międzykomórkowe, może być także odprowadzony wzdłuż nerwów czaszkowych.

Usuwanie zbędnych substancji $z$ płynu międzykomórkowego zachodzi w trakcie przepływu płynu mózgowo-rdzeniowego przez przestrzenie międzykomórkowe i „mieszania się" $z$ płynem międzykomórkowym; ustalono, że wymiana substancji zachodzi zarówno na drodze dyfuzji, jak i dzięki tzw. przepływowi konwekcyjnemu (ang. convection, bulk flow) (MESTRE i współaut. 2020).

W celu badania funkcji układu glimfatycznego, do płynu mózgowo-rdzeniowego podaje się znacznik (białko wyznakowane fluorescencyjnie lub izotopowo) lub, do krwioobiegu, związki o właściwościach paramagnetyczych, stosowane jako kontrast $\mathrm{w}$ obrazowaniu rezonansem magnetycznym (MRI). Znacznik lub kontrast odzwierciedlają ilość, sposób i dynamike przemieszczania się płynu mózgowo-rdzeniowego. W celu uzyskania bardziej szczegółowych danych, wykorzystuje się białka o różnej wielkości, pokonujące barierę krew-mózg (czyli aktywnie transportowane lub dyfundujace z kapilar pomiędzy wypustkami astrocytów) lub nie opuszczające łożyska naczyniowego. W przypadku znacznika fluorescencyjnego, można go wizualizować przy użyciu mikroskopu fluorescencyjnego lub dwufotonowego. Pod mikroskopem fluorescencyjnym analizuje się skrawki mózgu, wypreparowanego i utrwalonego po podaniu znacznika. Technologia mikroskopii dwufotonowej umożliwia obserwację znacznika u żywego zwierzęcia (znieczulonego, przytomnego lub nie), przez wypreparowany otwór w czaszce (kraniotomię). Obrazowanie przyżyciowe, w czasie rzeczywistym, umożliwia również rezonans magnetyczny.

\section{AKTYWNOŚĆ UKŁADU GLIMFATYCZNEGO A SEN - WPEYW ANESTEZJI}

Układ glimfatyczny jest potocznie rozumiany jako układ "detoksyfikujący" mózg. Swoją popularnonaukową sławę zawdzięcza tym badaniom prof. Nedergaard, które wykazały, że uczestniczy on w usuwaniu $z$ mózgu amyloidu $\beta$, nieprawidłowego białka przyczyniającego się do powstawania choroby Alzheimera. O roli układu glimfatycznego $\mathrm{w}$ patomechanizmie choroby Alzheimera i innych chorób neurodegeneracyjnych więcej przeczytać można w artykułach przeglądowych (PlOG i NEDERGAARD 2018, KEIR i BREEN 2020, OBARA-MichlEWSKA 2020). Wydaje się jednak, że najbardziej rozpoznawalna cechą układu glimfatycznego jest fakt, również będący odkryciem prof. Nedergaard, że jest on najbardziej aktywny podczas snu (XIE i współaut. 2013). Odkrycie zależności między snem a aktywniejszym w tym czasie układem glimfatycznym, usuwajacym zbędne metabolity gromadzace się w mózgu podczas dziennej aktywności, przyczyniło się do wielu spekulacji na temat roli snu w powstawaniu czy zapobieganiu chorobom neurodegeneracyjnym, a także do rozszerzenia teorii dotyczacej fizjologicznego znaczenia snu. Według obecnych hipotez, absolutna niezbędność snu dla ośrodkowego układu nerwowego (OUN) wynika $z$ faktu, że sen warunkuje prawidłowość wyższych funkcji poznawczych, w szczególności uczenia się i pamięci, a także umożliwia procesy homeostatyczne i naprawcze. Do drugiej kategorii, obok regulowania metabolizmu energetycznego mózgu i biosyntezy makromolekuł, zaliczono również usuwanie zbędnych metabolitów, czyli aktywność układu glimfatycznego (FRANK i HELLER 2019).

Wyróżnić można dwie zasadnicze fazy snu, występujace po sobie naprzemiennie: fazę snu wolnofalowego (ang. non-rapid eye movement, NREM), którą dodatkowo można podzielić na cztery etapy (N1-N4), oraz fazę snu paradoksalnego, REM (ang. rapid eye movement). Podczas zasypiania zapadamy, poprzez kolejne fazy N1-N4, w sen wolnofalowy, czyli inaczej sen głęboki, podczas którego następuje właściwa regeneracja organizmu - tempo metabolizmu, ciśnienie krwi, rytm oddechu i praca serca, temperatura ciała ulegaja obniżeniu. Następnie następuje faza REM, faza snu płytszego, $z$ marzeniami sennymi. Po niej często występuje krótkie wybudzenie i znowu zapadamy coraz głębiej w sen NREM - podczas nocy występuje najczęściej 4-6 pełnych cykli NREM-REM, trwających łącznie 6-8 godz. Każda $z$ faz snu, odmienna neurologicznie i psychologicznie, 
czuwanie: fale gamma $(12-28 \mathrm{~Hz})$ i beta $(>30 \mathrm{~Hz})$
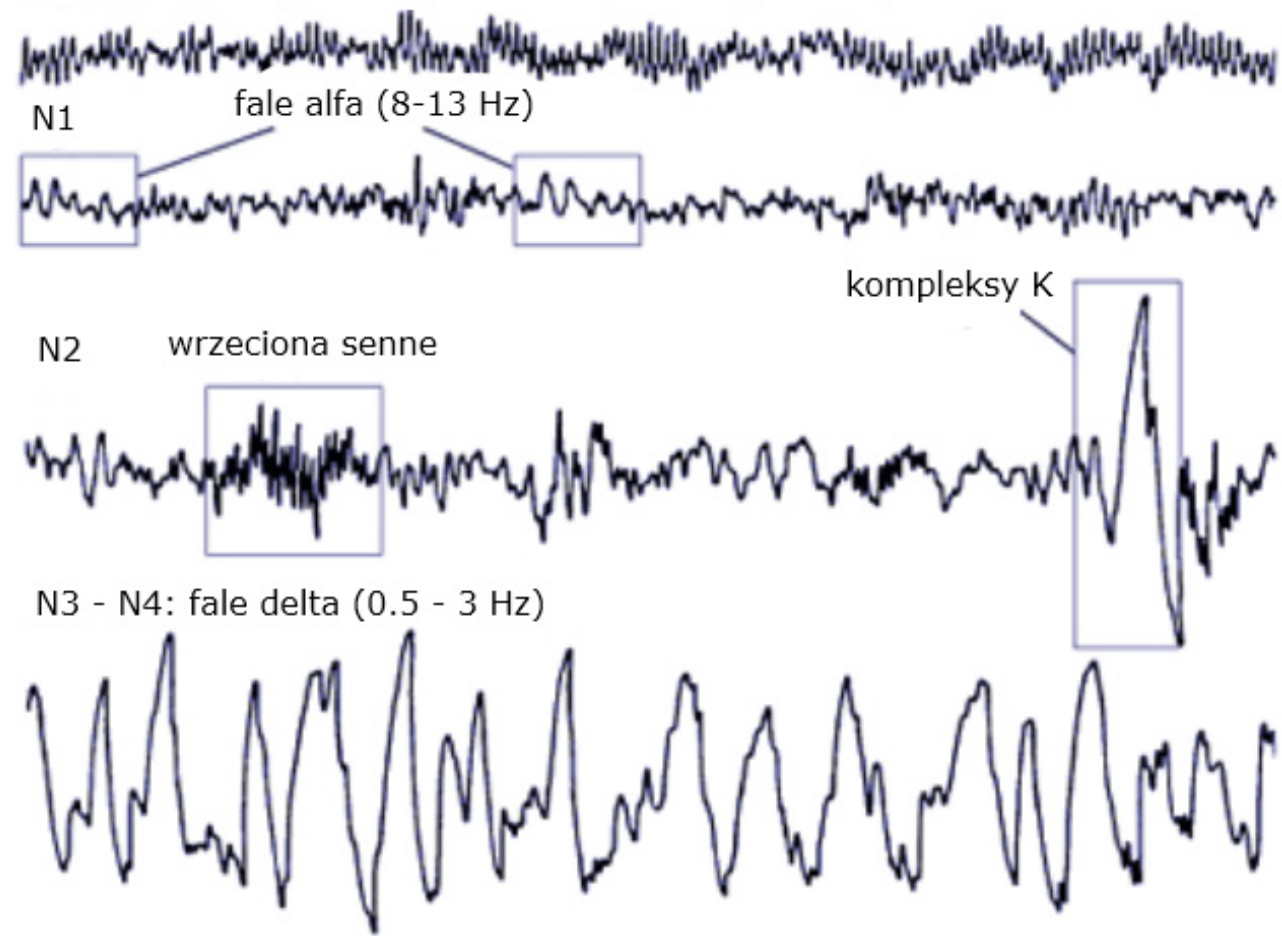

REM

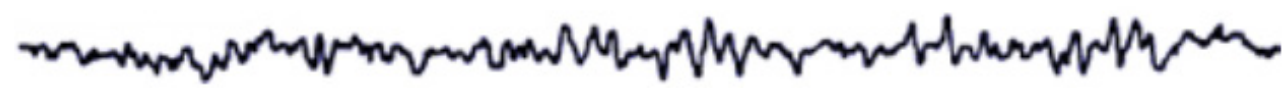

Ryc. 2. Zapis aktywności elektrycznej mózgu (EEG) w stanie czuwania i snu.

Według https://kevinbinz.com/2016/09/09/why-we-sleep/.

cechuje się charakterystycznym dla niej wzorem aktywności elektrycznej mózgu (elektroencefalogramu, EEG) (Ryc. 2). Podczas normalnej aktywności dziennej w zapisie EEG przeważaja fale gamma i beta, o najwyższej częstotliwości i małej amplitudzie. W stanie odprężenia, na leżąco z zamkniętymi oczami, na granicy zaśnięcia (faza N1), dominuja fale alfa o niskiej amplitudzie i częstotliwości. Po zaśnięciu i w miarę pogłębiania się snu, częstotliwość fal mózgowych dalej się zmniejsza, a zwiększa się ich amplituda: w fazie N2 pojawiaja się fale theta, a także charakterystyczne cechy zapisu EEG, wrzeciona senne i kompleksy $\mathrm{K}$. W fazie N3 i N4 obserwuje się fale delta, o najmniejszej częstotliwości (stąd sen głęboki, N4, określa się także wolnofalowym). Zapis EEG fazy REM ma charakterystykę mieszana niskonapięciowa, dodatkowo dominują w niej fale theta oraz beta i występuja tzw. fale piłokształtne. Uważa się, że prawidłowa struktura snu, czyli jego jakość, ma znaczenie zarówno dla funkcji poznawczych, jaki i dla funkcji homeostatycznych i regeneracyjnych, a więc także dla aktywności układu glimfatycznego.

XIE i współaut. (2013) podawali znacznik fluorescencyjny do płynu mózgowo-rdzenio- wego (iniekcja do zbiornika wielkiego, łac. cisterna magna) myszy w stanie czuwania, myszy śpiacych (trenowanych do zapadania w naturalny sen mimo dyskomfortu unieruchomienia, niezbędnego do przeprowadzenia obrazowania) oraz myszy poddanych anestezji za pomoca kombinacji ketamina-ksylazyna. Stan snu potwierdzano za pomoca EEG: pojawienie się rytmów o częstotliwości fal delta, przy jednoczesnym zmniejszeniu fal theta, alfa i beta. To przełomowe doświadczenie wykazało, że znacznik fluorescencyjny penetruje wraz $z$ płynem-mózgowo-rdzeniowym znacznie większy obszar tkanki mózgowej w przypadku myszy śpiących (zarówno naturalnie, jak i pod wpływem narkozy), niż u myszy czuwających. Interpretuje się to jako zwiększona, o ok. 60\%, aktywność układu glimfatycznego podczas snu. Badacze wskazali, że za zwiększoną penetrację znacznika w tkance, a więc większą objętość płynu mózgowo-rdzeniowego, odpowiada zwiększenie przestrzeni międzykomórkowej. Schematycznie ilustruje to Ryc. 3. Za powiększenie się objętości płynu wypełniajacego przestrzeń międzykomórkowa najprawdopodobniej odpowiada kurczenie się naczyń krwionośnych i astrocytów. 


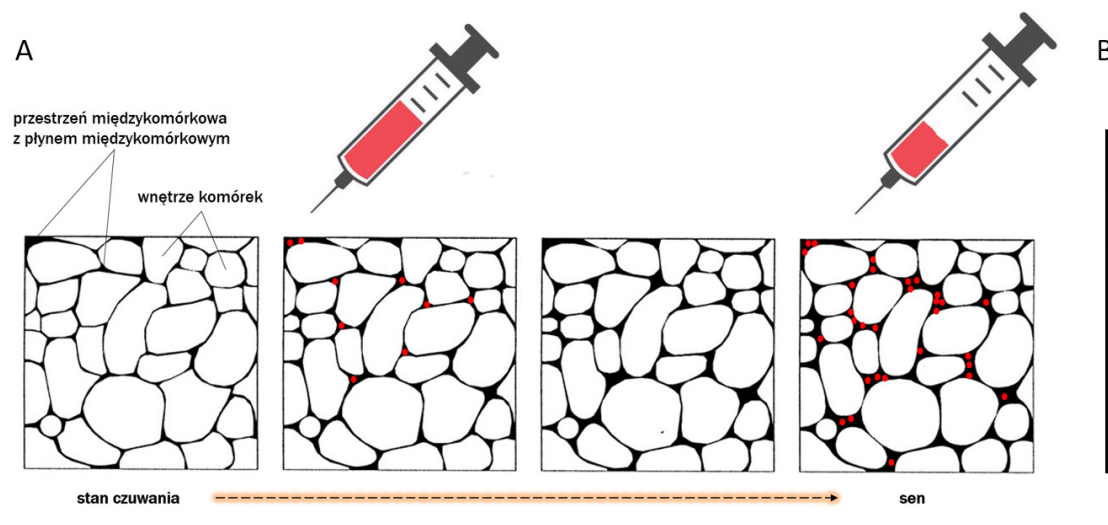

Ryc. 3. Schematyczne przedstawienie przestrzeni międzykomórkowych w stanie snu i czuwania (A) oraz obrazowanie aktywności układu glimfatycznego (B).

A) Podczas snu objętość przestrzeni międzykomórkowej zwiększa się, a więc więcej płynu mózgowo-rdzeniowego może do niej napłynąć w trakcie aktywności układu glimfatycznego. Jeśli do płynu mózgowo-rdzeniowego podany zostanie znacznik (np. fluorescencyjny), schematycznie zaznaczony jako czerwone kropki, to w trakcie snu do mózgu trafi więcej znacznika, co zostanie zobrazowane jako zwiększona aktywność układu glimfatycznego. B) Przykładowy obraz mózgu (przekrój poprzeczny) myszy po podaniu znacznika fluorescencyjnego do cisterna magna w czasie czuwania (opis metody w OBARA-MiCHLEWSKA i współaut. 2018).

Zależność między objętościa przestrzeni pozakomórkowej a funkcjonowaniem układu glimfatycznego była również badana w mysim modelu migreny, polegającym na wywołaniu rozszerzajaccej się depresji korowej (ang. cortical spreading depression, CSD). W tym badaniu znacznik fluorescencyjny podawany był do przestrzeni podpajęczynówkowej i obrazowany pod mikroskopem dwufotonowym. Zaobserwowano, że CSD wywołuje gwałtowne zmniejszenie sie przestrzeni okołonaczyniowej zarówno wokół tętnic położonych na powierzchni, jak i penetrujacych w głąb mózgu. Wykluczono zmianę średnicy naczyń, a zmniejszenie się objętości przestrzeni okołonaczyniowej korelowało $z$ gorsza penetracja znacznika, a więc dysfunkcja układu glimfatycznego (SCHAIN i współaut. 2017).

Zwiększona aktywność układu glimfatycznego (tj. większa penetrację znacznika w tkance) skorelowano $z$ neuroprzekaźnictwem noradrenergicznym. Noradrenalina (norepinefryna), wydzielana przez neurony miejsca sinawego (łac. locus corelueus, LC), jądra zlokalizowanego w górnej części pnia mózgu, odpowiada za stan pobudzenia i gotowości do reakcji na bodźce, ułatwia koncentrację, zapamiętywanie i przypominanie. Co istotne, najniższe poziomy noradrenaliny stwierdza się podczas snu, w stanie czuwania jej stężenie wzrasta o $180 \%$, a w przypadkach stresu i niebezpieczeństwa jej uwalnianie wzrasta jeszcze bardziej. Okresowy zanik aktywności komórek noradrenergicznych podczas snu zapobiega spadkowi wrażliwości receptorów noradrenergicznych, nie- ustannie aktywowanych w okresie czuwania. Przypuszcza się, że $\mathrm{w}$ ten sposób sen REM zwiększa zdolność czuwania za dnia (BERRIDGE i współaut. 2012).

Nedergaard i jej współpracownicy symulowali sen u myszy przez podawanie antagonistów receptorów adrenergicznych (prazosin, atipamezol, propranolol). Podanie koktajlu antagonistów wywołało sen o parametrach EEG zbliżonych do snu naturalnego (zwiększona proporcja częstotliwości w paśmie delta, przy obniżonej proporcji fal alfa i beta). Zastosowanie antagonistów receptorów adrenergicznych, analogicznie do snu, spowodowało aktywację układu glimfatycznego, wyrażoną zwiększona ilością znacznika fluorescencyjnego w mózgu (XIE i współaut. 2013).

Rola anestezji w regulowaniu aktywności układu glimfatycznego została przez grupę Nedergaard przebadana w sposób bardziej systematyczny (HABLITZ i współaut. 2019), jako odpowiedź na przeciwstawne wyniki badań otrzymane przez GAKUBA i współaut. (2018). Zastosowano sześć rodzajów anestezji o różnych mechanizmach działania na OUN: izofluran, izofluran $\mathrm{w}$ skojarzeniu $\mathrm{z}$ deksmedetomidyna, ketaminę $z$ ksylazyna, pentobarbital, a-chloralozę i tribromoetanol.

Izofluran jest m.in. pozytywnym modulatorem receptorów dla neurotransmitera hamujacego (kwasu $\gamma$-aminomasłowego, GABA), dzięki czemu aktywuje neurotransmisję hamująca. Jest też antagonista receptorów N-metylo-D-asparaginowych (NMDA), hamując neurotransmisję pobudzająca. Hamuje także kanały potasowe $\mathrm{K}_{2 \mathrm{P}}$. Deksmedetomidyna i ksylazyna sa agonistami recepto- 
rów a2-adrenergicznych, a więc zmniejszaja uwalnianie noradrenaliny przez neurony LC. Pentobarbital, a-chloraloza i tribromoetanol są pozytywnymi modulatorami receptorów GABA, przy czym tribromoetanol ma dodatkowe właściwości farmakologiczne, jak np. oddziaływanie $z$ receptorami adrenergicznymi i muskarynowymi. Wykazano, że podczas działania tych anestetyków, które najbardziej hamowały uwalnianie nordrenaliny (w kolejności od najsilniejszego hamowania: ketamina/ksylazyna > izofluran/deksmedetomidyna > pentobarbital > a-chloraloza > tribromoetanol > izofluran), zapis EEG najlepiej odwzorowywał naturalny sen, charakteryzujący się falami o wyższej amplitudzie, ale o mniejszej częstotliwości (większy udział fal delta). Układ glimfatyczny był najbardziej aktywny podczas działania anestezji hamujacej wydzielanie noradrenaliny, gdyż taka najlepiej modeluje naturalny sen wolnofalowy, dodatkowo potwierdzany spowolnieniem rytmu pracy serca (HABLITz i współaut. 2019, BECHET i współaut. 2020).

Zależność stopnia aktywacji układu glimfatycznego od rodzaju anestezji była badana również przyżyciowo (MRI). Tu również wykazano powyżej opisana zależność. Co ciekawe, zapis EEG prowadzony pod narkoza izofluranem oraz izofluranem $z$ deksmedetomidyna wykazał, iż ta pierwsza charakteryzuje się „snem przerywanym”: po okresach, w których w zapisie EEG dominowały fale o większej amplitudzie a niższej częstotliwości, pojawiały się okresy zapisu charakterystyczne dla stanu czuwania (mimo iż z punktu widzenia eksperymentatora zwierzę cały czas spało i nie reagowało na bodźce). Natomiast podczas anestezji izofluranem $z$ deksmedetomidyna, zapis EEG cechował się ciagłym zwiększeniem amplitudy i zmniejszeniem częstotliwości. Obserwowano także wrzeciona senne (BENVENISTE i współaut. 2017). Powyższe wyniki badań na myszach zostały także potwierdzone na szczurach. Badanie MRI wykazało, że dystrybucja kontrastu gadodiamidu zależy zarówno od przepływu płynu mózgowo-rdzeniowego, jak i krążenia krwi, a także potwierdziło, że aktywność układu glimfatycznego, odpowiedzialnego za usuwanie znacznika $z$ mózgu, jest modulowana przez sen i anestezję (TAOKA i współaut. 2018). Obrazowanie MRI przeprowadzone przez CAI i współaut. (2020) również potwierdziło znane właściwości układu glimfatycznego, lecz dodatkowo wskazało, że dystrybucja kontrastu jest w mózgu szczura heterogenna (największa w części grzbietowej mózgowia, najniższa w śródmózgowiu i wzdłuż brzusznej powierzchni mózgu), przy czym zmienność ta korelowała nie tylko $z$ unaczynieniem, ale także $z$ fizjologicznymi różnicami temperatury występującymi pomiędzy strukturami mózgu. Podsumowując, układ glimfatyczny jest znacznie aktywniejszy podczas snu, ale jakość snu także ma znaczenie, tj. w kontekście działania układu glimfatycznego najefektywniejszy byłby sen głęboki, NREM.

\section{AKWAPORYNA 4 - ŁACZNIK MIEDZY} SNEM A FUNKCJONOWANIEM UKEADU GLIMFATYCZNEGO?

Niedawno zaproponowano, że zależność między jakością snu a funkcją układu glimfatycznego może mieć miejsce $\mathrm{w}$ przypadku osób cierpiących na idiopatyczne wodogłowie normotensyjne. U takich pacjentów często dochodzi do wybudzeń na skutek bezdechu sennego. Badania $z$ użyciem mikroskopii elektronowej wykazały w materiale biopsyjnym obniżona ekspresję Aqp4 w wypustkach astrocytów kontaktujacych się $\mathrm{z}$ naczyniami włosowatymi w mózgu. Ponadto, MRI u pacjentów $z$ wodogłowiem zaobserwowano opóźnienie w odprowadzaniu kontrastu $z$ mózgu, co wskazuje na upośledzenie funkcjonowania ich układu glimfatycznego (ROMAN i współaut. 2019). Co niezwykle interesujace, stwierdzono że polimorfizmy (ang. single nucleotide polymorphism, SNP) w genie kodującym Aqp4 u ludzi wpływaja zarówno na usuwanie amyloidu $\beta$, jak i na jakość snu, która u osób badanych oceniano na podstawie kwestionariusza jakości snu Pittsburgh. Ilość amyloidu $\beta$ w mózgu określano natomiast $z$ wykorzystaniem tomografii pozytronowej (ang. positron emission tomography, PET), po podaniu wyznakowanych radioizotopowo jego znaczników. Poszczególne warianty genu Aqp4 miały odmienny wpływ na parametru snu, np. wariant rs72878776 był skorelowany $z$ ogólna gorsza jakością snu, natomiast obecność innych SNPów (rs491148, rs9951307, rs7135406, rs3875089, rs151246) wpływała na czas zasypiania, a kolejnych na długość snu (rs72878776, rs491148, rs2339214) (RAINEY-SMITH i współaut. 2018).

Z drugiej strony, już krótka, dwugodzinna anestezja sewofluranem podczas splenektomii, powodowała zależny od czynnika transkrypcyjnego NFAT5 (ang. nuclear factor of activated $\mathrm{T}$ cells 5) wzrost ekspresji Aqp4 $\mathrm{w}$ mózgu u szczurów eksperymentalnych, ale także u pacjentów poddawanych resekcji guza mózgu. Co istotne w kontekście aktywności układu glimfatycznego, ani propofol ani pentobarbital nie wpływały na poziom ekspresji Aqp4. Wydaje się, że sewofluran może mieć właściwości neuroprotekcyjne, gdyż z zależnym od sewofluranu zwiększeniem ekspresji Aqp4 korelowało zintensyfiko- 
wane usuwanie $z$ mózgu $\beta$-amyloidu, który akumulował się w niespecyficznej odpowiedzi na uraz zwiazany $z$ procedura chirurgiczna (GAO i współaut. 2019). Badania te potwierdzaja hipotezy stawiane pierwotnie na podstawie doświadczeń na myszach, o udziale Aqp4 w funkcjonowaniu układu glimfatycznego, a także o związku między snem i praca układu glimfatycznego, jako elementów patomechanizmu chorób neurodegeneracyjnych, gdyż udowodniono, że niedobór snu powoduje akumulację amyloidu $\beta$ (ZHANG i współaut. 2020).

Niedawno pojawiło się również doniesienie wskazujące, że oprócz Aqp4, także inne kanały, tj. paneksyny, moga przyczyniać się do regulacji pracy układu glimfatcznego (Shestopalov i współaut. 2017). Paneksyny to w większości duże kanały błonowe (choć moga być też obecne np. w błonach siateczki śródplazmatycznej czy aparatu Golgiego), łacczace kompartmenty zewnatrz- i wewnattrzkomórkowy, umożliwiajac transport jonów i małych cząsteczek, w szczególności adenozyno-5'-trifosforanu (ATP). Stwierdzono, że myszy $z$ knock-outem paneksyny 1 cierpia na poważne zaburzenia cyklu dobowego (KovALZON i współaut. 2017). Może to wynikać $z$ faktu, że zakłócenia transportu ATP powoduja zaburzenia syntezy adenozyny, będacej regulatorem snu. ATP jest przez enzymy zewnątrzkomórkowe metabolizowany do adenozyny, której poziom wzrasta w ciagu dnia, zwiększajac tzw. presję snu (HAYDON 2017). Przypisywana paneksynom rola $\mathrm{w}$ modulacji funkcji układu glimfatycznego mogłaby wynikać także $z$ regulacji przepływu krwi, gdyż wykazano, że paneksyny sa zaangażowane w zależne od komórek śródbłonka rozszerzenie się naczyń tętniczych (SHESTOPALOV i współaut. 2017).

\section{AKTYWNOŚĆ UKŁADU GLIMFATYCZNEGO A SEN - WPEYW POZYCJI CIAŁA}

Ważnym elementem snu jest pozycja w jakiej spimy. Kiedy unieruchamiano myszy w pozycji głowa w dół, aktywność układu glimfatycznego spadała w stopniu porównywalnym do niskiego poziomu obserwowanego u myszy nieposiadajacych Aqp4 (Aqp4 KO). Dodatkowo stwierdzono, że zarówno niefizjologiczna pozycja, knockout Ap4, jak i farmakologiczne zahamowanie aktywności układu glimfatycznego przy pomocy acetazolamidu (inhibitora anhydrazy węglanowej, który obniża produkcję płynu mózgowo-rdzeniowego) powodowały, że nie następował spadek poziomu kwasu mlekowego w mózgu, co normalnie ma miejsce po zapadnięciu w sen. Zgodnie $z$ tym, pozbawianie myszy snu po- wodowało akumulację mleczanu w mózgu. Ponadto, wymienione manipulacje (pozycja ciała, Aqp4 KO, acetazolamid) powodowały, że nie dochodziło do wzrostu stężenia mleczanu w węzłach chłonnych szyjnych i pachwinowych. Wyniki te świadcza o odprowadzaniu mleczanu $z$ mózgu podczas snu w sytuacji fizjologicznej. Autorzy zaproponowali więc, że mleczan mógłby stanowić naturalny marker aktywności układu glimfatycznego przy badaniach nad cyklem dobowym (LUNDGAARD i współaut. 2017). Wpływ pozycji ciała podczas snu na aktywność układu glimfatycznego badano także w warunkach unieruchamiania myszy i szczurów w pozycji brzusznej, bocznej i grzbietowej. Stosując zarówno obrazowanie ex vivo, jak $\mathrm{i}$ in vivo wykazano, że najkorzystniejsza $z$ punktu widzenia aktywności układu glimfatycznego jest pozycja boczna, gdyż odzwierciedla pozycję naturalnie przyjmowana podczas snu przez gryzonie (LEE i współaut. 2015). W tym miejscu należy doprecyzować, że myszy nie przyjmują pozycji „bocznej” podczas snu, a co najwyżej przechylają głowę pod katem ok. $30^{\circ}$ wtedy, gdy śpia zwinięte w kłębek. Natomiast pozycja boczna, opisywana przez LEE i współaut. (2015), oddaje faktycznie boczna pozycję przyjmowana przez śpiące szczury. Prof. Nedergaard argumentuje, że ponieważ większość ssaków, a w szczególności naczelne, najczęściej śpi na boku, pozycja ta ewoluowała w celu optymalizacji pracy układu glimfatycznego (LEE i współaut. 2015).

Ponieważ zaobserwowano, że pacjenci $Z$ chorobami neurodegeneracyjnymi częściej wybieraja do snu pozycję na plecach, podczas gdy zdrowi ochotnicy dłużej spali na boku (LEVENDOWSKI i współaut. 2019), postanowiono zbadać podłoże tej różnicy. U człowieka, w pozycji leżącej krew odpływa $z$ mózgu głównie przez żyły szyjne wewnętrzne, natomiast $\mathrm{w}$ pozycji $z$ uniesiona głowa krew odpływa przede wszystkim przez nadtwardówkowe sploty żylne w kanale kręgowym i przez żyły kręgowe. Pilotażowe badanie sonograficzne, przeprowadzone niestety na niewielkiej liczbie osób wykazało, że pozycja boczna charakteryzuje się optymalnym przepływem w żyle szyjnej wewnętrznej. W pozycji grzbietowej światło obu żył było zmniejszone, podczas gdy w pozycji bocznej, tylko jednej (zależnie od tego, czy badany leżał na prawym, czy lewym boku). Autorzy badania spekulują więc, że instynktowne wybieranie do snu pozycji bocznej jest związane $z$ tym, że optymalne krażenie żylne umożliwia niezakłóconą pracę układu glimfatycznego, a tym samym przeciwdziała chorobom neurodegeneracyjnym (SIMKA i współaut. 2019). W zwiazku $z$ tym, wskazano na 
konieczność przyjrzenia się pod tym katem relatywnie niedawno opisanej jednostce chorobowej, przewlekłej niewydolności mózgowo-rdzeniowych naczyń żylnych, towarzyszacej nie tylko stwardnieniu rozsianemu, ale także chorobie Alzheimera i Parkinsona, jako elementowi potencjalnie przyczyniajacemu się do nieprawidłowego usuwania zbędnych metabolitów z mózgu (SIMKA i SKUŁa 2019).

\section{PODSUMOWANIE}

Powstanie koncepcji układu glimfatycznego, mimo wzbudzenia wielu kontrowersji, pozwoliło na zrewidowanie dotychczasowej wiedzy na temat mechanizmu przepływu płynu mózgowo-rdzeniowego, w szczególności zaangażowania astrocytów, komórek gleju, którym układ glimfatyczny zawdzięcza litere "g" w nazwie. Prawdziwie przełomowe okazało się odkrycie, że układ glimfatyczny jest najaktywniejszy podczas snu. Ukazuje się coraz więcej doniesień o zaangażowaniu układu glimfatycznego w patomechanizm wielu chorób, m.in. Alzheimera i Parkinsona. Fakt, iż układ glimfatyczny jest aktywniejszy podczas snu i wówczas dokonuje eliminacji $z$ mózgu m.in. złogów amyloidu $\beta$ ma niezwykle istotne implikacje kliniczne. Nawet pozornie trywialna kwestia pozycji ciała podczas snu może mieć fundamentalne znaczenie dla przeciwdziałania chorobom neurodegeneracyjnym.

Wykazano także, że tkankowa dostępność takich leków jak nalokson, oksykodon, podanych dooponowo, zależy od rodzaju użytej anestezji. Zgodnie $z$ hipoteza, biodostępność tych modelowych substancji w mózgu i rdzeniu kręgowym była większa w przypad$\mathrm{ku}$ anestezji zwiazanej $\mathrm{z}$ aktywnościa wolnofalowa mózgu (LiLIUs i współaut. 2019). W kontekście zaburzeń snu, bardzo ciekawa jest kwestia nakładajacych się na przebieg innych chorób, polimorfizmów w genie Aqp4. Po raz kolejny doceniono wartość higieny snu, tj. pozycji w jakiej śpimy, gdyż może mieć ona fundamentalne znaczenie dla zdrowia naszego układu nerwowego. Niewatpliwie nadal pozostaje więcej pytań niż odpowiedzi, a na potwierdzenie oczekuja m.in. hipotezy o wpływie pankesyn czy patologii szyjnych naczyń żylnych, na aktywność układu glimfatycznego. I odwracając problem, być może podczas neuroobrazowania aktywności układu glimfatycznego u ludzi, należy brać pod uwagę pozycję i stan naczyń szyjnych badanego (CZYŻEWSKA i współaut. 2015)?

Ponadto, należy zaznaczyć, że chociaż istnieje wiele podobieństw między stanem snu $\mathrm{i}$ stanem podczas narkozy, jednak jak dotą nie zidentyfikowano zwiazku chemicznego, który idealnie odwzorowywałby natu- ralny sen, wraz $z$ jego złożona struktura $i$ własnościami elektrofizjologicznymi mózgu. Badania prof. Błasiaka, prowadzone $z$ użyciem narkozy uretanowej wykazały, że mimo iż zapis EEG $z$ kory mózgowej jest bardzo zbliżony do snu naturalnego, jednak aktywność neuronów jądra nadskrzyżowaniowego (ang. suprachiasmatic nucleus, SCN), odpowiedzialnego za kontrolę rytmu dobowego, stanu snu i czuwania, nie odpowiada snowi naturalnemu (WALCZAK i BŁASIAK 2017). Bezpośrednie skorelowanie aktywności układu glimfatycznego $z$ aktywnościa struktur odpowiedzialnych za kontrolę snu i czuwania, a więc LC czy SCN, nie było jak dotąd badane przez prof. Nedergaard. Inna watpliwość dotyczy stosowania acetazolamidu (LUNDGAARD i współaut. 2017) jako inhibitora układu glimfatycznego, gdyż, oprócz hamowania wydzielania płynu mózgowo-rdzeniowego, powodował on także kurczenie się astrocytów (FLORENCE i współaut. 2012), co może wpływać na objętość przestrzeni zewnattrzkomórkowej.

Należy więc pamiętać, że modele zwierzęce, które wykorzystuje się do badania snu i zależności układu glimfatycznego, moga dość daleko odbiegać od warunków fizjologicznych, a złożoność zagadnienia może utrudniać wnioskowanie co do efektów stosowanych srodków farmakologicznych.

Streszczenie

Układ glimfatyczny, nazwany i opisany przez prof. Maiken Nedergaard, jest w mózgu funkcjonalnym odpowiednikiem układu limfatycznego. Mechanizm jego działania opiera się na przepływie płynu mózgowo-rdzeniowego, stanowiącego nośnik dla rozpuszczonych w nim zbędnych produktów metabolizmu komórkowego, m.in. amyloidu $\beta$, które muszą zostać odprowadzone poza mózg. Liczne dowody naukowe wskazuja, że układ glimfatyczny jest najbardziej aktywny podczas snu i to wówczas dochodzi do usuwania $z$ mózgu zbędnych metabolitów. Dla efektywnej pracy układu glimfatycznego istotna jest prawidłowa architektura snu, a konkretnie odpowiednia długość fazy snu głębokiego, wolnofalowego (tj. snu non-REM). Pobudzenie aktywności układu glimfatycznego można odtworzyć za pomoca anestetyków, w szczególności tych, które obniżaja uwalnianie noradrenaliny (norepinefryny), podtrzymujacej stan czuwania. Na wydajność pracy układu glimfatycznego wpływa również pozycja ciała podczas snu. Uważa się, że pozycja boczna, najczęściej przybierana przez ssaki, w tym człowie$k a$, jest optymalna $z$ punktu widzenia usuwania $z$ mózgu potencjalnie szkodliwych substancji. Odkrycie tych zależności wzbudza ogromne zainteresowanie i nadzieje, że poprzez wpływanie na pracę układu glimfatycznego będzie można zapobiegać lub choćby łagodzić przebieg chorób ośrodkowego układu nerwowego, w tym chorób neurodegeneracyjnych.

\section{LITERATURA}

Absinta M., Ha S. K., Nair G., Sati P., Luciano N. J., Palisoc M., Louveau A., Zaghloul K. 
A., PitTaluga S., Kipnis J., Reich D. S., 2017. Human and nonhuman primate meninges harbor lymphatic vessels that can be visualized noninvasively by MRI. Elife. 6, doi:10.7554/ eLife.29738.

Aspelund A., Antila S., ProulX S. T., Karlsen T. V., Karaman S., Detmar M., WiIg H., Alitalo K., 2015. A dural lymphatic vascular system that drains brain interstitial fluid and macromolecules. J. Exp. Med. 212, 991-999.

Bechet N. B., Kylkilahti T. M., Mattsson B., PeTRASOVA M., SHANBHAG N. C., LundGAARD I., 2020. Light sheet fluorescence microscopy of optically cleared brains for studying the glymphatic system. J. Cereb. Blood Flow Metab. doi.org/10.1177/0271678X20924954.

Benveniste H., LeE H., Ding F., SUn Q., Al-BizRI E., MAKaryus R., PRobst S., NEDERGAard M., STEIN E. A., LU H., 2017. Anesthesia with dexmedetomidine and low-dose isoflurane increases solute transport via the glymphatic pathway in rat brain when compared with high-dose isoflurane. Anesthesiology 127, 976988.

BerRidge C. W., Schmeichel B. E., Espana R. A., 2012. Noradrenergic modulation of wakefulness/arousal. Sleep Med. Rev. 16, 187-197.

CaI X., QIaO J., KUlKarni P., HaRding I. C., EBONG E., FERRIS C. F., 2020. Imaging the effect of the circadian light-dark cycle on the glymphatic system in awake rats. Proc. Natl. Acad. Sci. USA 117, 668-676.

CZYŻEWSKA D., KRYSIUK K., DOBRZYCKI K., UsTYMOWICZ A., 2015. Ultrasound assessment of the jugular and vertebral veins in healthy individuals: selected physiological aspects and morphological parameters. J. Ultrason. 15, 267-273.

Florence C. M., Baillie L. D., Mulligan S. J., 2012. Dynamic volume changes in astrocytes are an intrinsic phenomenon mediated by bicarbonate ion flux. PLoS. One. 7, e51124.

FRANK M. G. HELLER H. C., 2019. The function(s) of sleep. Handb. Exp. Pharmacol. 253, 3-34.

GaKuba C., Gaberel T., Goursaud S., Bourges J., Di P. C., Quenault A., Martinez De L. S., VIVIEN D., GAUBERTI M., 2018. General anesthesia inhibits the activity of the "glymphatic system". Theranostics 8, 710-722.

GaO X., Ming J., LiU S., LaI B., FAng F., CANG J., 2019. Sevoflurane enhanced the clearance of Abeta1-40 in hippocampus under surgery via up-regulating AQP-4 expression in astrocyte. Life Sci. 221, 143-151.

HablitZ L. M., Vinitsky H. S., Sun Q., STAEger F. F., Sigurdsson B., MORTEnsen K. N., LiLIUS T. O., NEDERGAARD M., 2019. Increased glymphatic influx is correlated with high EEG delta power and low heart rate in mice under anesthesia. Sci. Adv. 5, eaav5447.

HAYDON P. G., 2017. Astrocytes and the modulation of sleep. Curr. Opin. Neurobiol. 44, 2833.

Iliff J. J., Wang M., Liao Y., Plogg B. A., Peng W., Gundersen G. A., Benveniste H., Vates G. E., DeAne R., Goldman S. A., NAGelhus E. A., NEDERGAARD M., 2012. A paravascular pathway facilitates CSF flow through the brain parenchyma and the clearance of in terstitial solutes, including amyloid beta. Sci. Transl. Med. 4, 147ra111

ILIFF J. J., WANG M., ZEPPENFELD D. M., VENKAtaraman A., Plog B. A., liao Y., Deane R., NEDERGAARD M., 2013. Cerebral arterial pulsation drives paravascular CSF-interstitial fluid exchange in the murine brain. J. Neurosci. 33, 18190-18199.

Jessen N. A., MunK A. S., LundgaArd I., NEDERGAARD M., 2015. The Gglymphatic system: A beginner's guide. Neurochem. Res. 40, 25832599.

KeIR L. H. M., BREEN D. P., 2020. New awakenings: current understanding of sleep dysfunction and its treatment in Parkinson's disease. J. Neurol. 267, 288-294.

KHASAWNEH A. H., GARLING R. J., HARRIS C. A., 2015. Cerebrospinal fluid circulation: What do we know and how do we know it? Brain Circ. 4, 14-18.

Kovalzon V. M., MOISEenKo L. S., Ambaryan A. V., KurTenbach S., Shestopalov V. I., PANCHIN Y. V., 2017. Sleep-wakefulness cycle and behavior in pannexin1 knockout mice. Behav. Brain Res. 318, 24-27.

Lee H., Xie L., Yu M., Kang H., Feng T., Deane R., LOGAN J., NEDERGAARD M., BENVENISTE H., 2015. The effect of body posture on brain glymphatic transport. J. Neurosci. 35, 1103411044.

Levendowski D. J., Gamaldo C., St Louis E. K., Ferini-STRAmbi L., Hamilton J. M., Salat D., WESTBROOK P. R., BERKA C., 2019. Head position during sleep: potential implications for patients with neurodegenerative disease. J. Alzheimers. Dis. 67, 631-638.

Lilius T. O., BlomQvist K., Hauglund N. L., LiU G., Staeger F. F., Baerentzen S., DU T., AHLSTROM F., BACKMAN J. T., KALso E. A., Rauhala P. V., NEDERgaARD M., 2019. Dexmedetomidine enhances glymphatic brain delivery of intrathecally administered drugs. J. Control Release 304, 29-38.

Louveau A., Smirnov I., Keyes T. J., Eccles J. D., Rouhani S. J., PESKE J. D., DERECKI N. C., Castle D., Mandell J. W., Lee K. S., HARRIS T. H., KIPNIS J., 2015. Structural and functional features of central nervous system lymphatic vessels. Nature 523, 337-341.

LundGaARD I., LU M. L., YANG E., Peng W., MesTRE H., Hitomi E., DEANE R., NEDERGAard M., 2017. Glymphatic clearance controls statedependent changes in brain lactate concentration. J. Cereb. Blood Flow Metab 37, 21122124.

Mestre H., Hablitz L. M., Xavier A. L., Feng W., Zou W., Pu T., Monai H., Murlidharan G., Castellanos Rivera R. M., Simon M. J., PIKe M. M., Pla V., Du T., KRESS B. T., Wang X., PloG B. A., THRANe A. S., LUndGaARD I., ABE Y., YASUI M., ThOMAS J. H., XIAO M., HiRAsE H., ASOKAN A., ILIFF J. J., NEDERGAARD M., 2018. Aquaporin-4-dependent glymphatic solute transport in the rodent brain. eLife. 7 , doi. org/10.7554/eLife.40070.001.

Mestre H., MORI Y., NEDERGAARD M., 2020. The brain's glymphatic system: current controversies. Trends Neurosci. 43, 458-466.

OBARA-MichlewsKa M., 2020. Ty śpisz, a on pracuje - rola układu glimfatycznego $w$ usprawnianiu pracy mózgu. Wszechświat 121, 5-13.

Obara-Michlewska M., Ding F., POPEK M., VERKHRATSKY A., NEDERGAARD M., ZIELINSKA M., AlBRECHT J., 2018. Interstitial ion homeostasis and acid-base balance are maintained in oedematous brain of mice with acute toxic liver failure. Neurochem. Int. 118, 286-291.

PLOG B. A. NEDERGAARD M., 2018. The glymphatic system in central nervous system health and disease: past, present, and future. Annu. Rev. Pathol. 13, 379-394. 
Rainey-SMith S. R., MazZucchelli G. N., VilleMAGNe V. L., BROWN B. M., PORTER T., WEINBORN M., BUCKS R. S., MILICIC L., SOHRABI H. R., TAdDei K., Ames D., MARUfF P., Masters C. L., Rowe C. C., Salvado O., Martins R. N., Laws S. M., 2018. Genetic variation in Aquaporin-4 moderates the relationship between sleep and brain Abeta-amyloid burden. Transl. Psychiatry 8, 47.

ROMAN G. C., JACKSON R. E., FUNG S. H., ZHANG Y. J., VERMA A. K., 2019. Sleep-disordered breathing and idiopathic normal-pressure hydrocephalus: recent pathophysiological advances. Curr. Neurol. Neurosci. Rep. 19, 39.

SCHAIN A. J., MELO-CARRILlO A., StRAsSMAN A. M., BURSTEIN R., 2017. Cortical spreading depression closes paravascular space and impairs glymphatic flow: implications for migraine headache. J. Neurosci. 37, 2904-2915.

ShestopaloV V. I., PANCHIN Y., TARASOVA O. S. GaYNullina D., Kovalzon V. M., 2017. Pannexins are potential new players in the regulation of cerebral homeostasis during sleep-wake cycle. Front Cell Neurosci. 11, 210.

SheTTY A. K. ZANIRATI G., 2020. The interstitial system of the brain in health and disease. Aging Dis. 11, 200-211.

SimkA M., SKUla M., 2019. Potential involvement of impaired venous outflow from the brain in neurodegeneration: lessons learned from the research on chronic cerebrospinal venous insufficiency. Rev. Recent Clin. Trials 14, 235236.
SIMKA M., CZAJA J., KOWALCZYK D., 2019. Collapsibility of the internal jugular veins in the lateral decubitus body position: A potential protective role of the cerebral venous outflow against neurodegeneration. Med. Hypotheses 133, 109397.

TAOKA T., Jost G., Frenzel T., NAganawa S., PIETSCH H., 2018. Impact of the glymphatic system on the kinetic and distribution of gadodiamide in the rat brain: observations by dynamic MRI and effect of circadian rhythm on tissue gadolinium concentrations. Invest. Radiol. 53, 529-534.

VERKHRATSKY A., HO M. S., VARDJAN N., ZOREC R., PARPURA V., 2019. General pathophysiol ogy of astroglia. Adv. Exp. Med. Biol. 1175, 149-179.

WALCZAK M. BŁASIAK T., 2017. Midbrain dopaminergic neuron activity across alternating brain states of urethane anaesthetized rat. Eur. J. Neurosci. 45, 1068-1077.

Xie L., Kang H., Xu Q., Chen M. J., LiaO Y., THIYAGARAJAN M., O'DONNELl J., CHRISTENSEN D. J., NichOlson C., IllFF J. J., TAKANO T., DEANE R., NEDERGAARD M., 2013. Sleep drives metabolite clearance from the adult brain. Science 342, 373-377.

ZHANG R., LIU Y., Chen Y., Li Q., Marshall C., Wu T., Hu G., XIAO M., 2020. Aquaporin 4 deletion exacerbates brain impairments in a mouse model of chronic sleep disruption. CNS Neurosci. Ther. 26, 228-239

KOSMOS Vol. 69, 3, 491-500, 2020

\section{MARTA OBARA-MichlEWSKA}

Department of Neurotoxicology, Mossakowski Medical Research Centre PAS, 5 Pawinskiego Str., 02-106 Warszawa, E-mail:mobara@ imdik.pan.pl

THE ROLE OF SLEEP IN GLYMPHATIC SYSTEM FUNCTION

Summary

The glymphatic system, named and described by Professor Maiken Nedergaard, is the functional equivalent of the lymphatic system in the brain. The mechanism of its action is based on the flow of the cerebrospinal fluid, which is a carrier for redundant products of cellular metabolism dissolved in it, e.g. $\beta$ amyloid that must be drained outside the brain. Numerous scientific evidence shows that the glymphatic system is most active during sleep and this is when unnecessary metabolites are drained from the brain. For the effective work of the glymphatic system, the correct sleep architecture is important, namely the appropriate length of the deep, slow-wave sleep (i.e. nonREM sleep). The stimulation of the glymphatic system activity can be reproduced with the help of anesthetics, in particular those that reduce the release of norepinephrine (norepinephrine), which maintains wakefulness. The position of the body during sleep also affects the efficiency of the glymphatic system. It is believed that the lateral position, most often assumed by mammals, including humans, is optimal from the point of view of removing potentially harmful substances from the brain. The discovery of these dependencies arouses great interest and hopes that by influencing the work of the glymphatic system, it will be possible to prevent or even alleviate the course of central nervous system diseases, including neurodegenerative diseases..

Key words: akwaporyna 4, astrocytes, cerebrospinal fluid, glymphatic system, sleep phases 